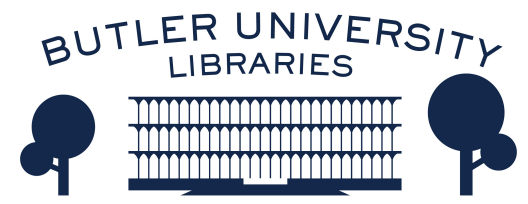

Journal of Hindu-Christian Studies

Volume 25

Article 14

November 2012

\title{
A Collection of Book Reviews
}

\author{
Edward Ulrich
}

Follow this and additional works at: https://digitalcommons.butler.edu/jhcs

Part of the Religion Commons

\section{Recommended Citation}

Ulrich, Edward (2012) "A Collection of Book Reviews," Journal of Hindu-Christian Studies: Vol. 25, Article 14.

Available at: https://doi.org/10.7825/2164-6279.1520

The Journal of Hindu-Christian Studies is a publication of the Society for Hindu-Christian Studies. The digital version is made available by Digital Commons @ Butler University. For questions about the Journal or the Society, please contact cbauman@butler.edu. For more information about Digital Commons @ Butler University, please contact digitalscholarship@butler.edu. 
takes on the challenge of creatively reconstructing directions for Dalit theology that are practical, biblical, inclusionary and liberative. These creative moves represent the most substantial and enriching section of the book. Moreover, in this contribution the vistas of theology are opened up to address concerns that include Dalits and non-Dalits. A more universal role is carved out for Dalit visions. All human beings and their eventual liberation matter to Dalit communities. In this sense Dalit theology is not merely an assertion of one human particularity but an aspiration for the liberation of all human beings.

There are a couple of critical comments I wish to register. First, Rajkumar's interpretation of the caste system replicates the same weakness that he identifies with Dalit theology: robust in churning out convincing theory but ineffectual when accounting for actual practice. His interpretation maps out the stringent divisions and blatant discriminations that underpin the rationale of caste system. This is no doubt an effective way of maintaining great distance between the Dalit's world of pollution and the Caste community's world of purity. Yet Rajkumar turns a blind eye towards the incalculable and boundless practices of Dalit subversions, Caste-Dalit negotiations, and Caste resignations that live and proliferate in the space in-between such theoretical formulations of purity and pollution. An uncritical inflation of fixity and negligent disregard of fluidity in the functioning of purity and pollution reinforces a stereotype of the power of caste communities in contrast to the powerlessness of the Dalit. Thus, even if useful for valorizing a bridging role for Jesus in the theoretical caste-Dalit divide, one is left with the unhelpful erasure of overt and covert manifestations of the calculating practices of Dalit agency. No wonder then that Rajkumar is stuck with the language of "victims" in referencing Dalits: "The Dalits are the victims of a social system, which sought (and still seeks) to maintain a feigned notion of auspiciousness, purity and pollution." (p. 19).

Second, I am not convinced that "practical efficacy" of Dalit theology ought to be the single criterion by which one evaluates the discipline. Surely meaningfulness and metaphysical plausibility can be added to the effectiveness of theology. But even if one lets Rajkumar have his praxiological cake alone one must ask the question as to whether the people eating the cake have had much to say on the matter of whether it is satisfactory as their meal? Perhaps what has emerged as Dalit theology in academe-produced texts does not get transferred to aid Dalit Christian practice on the ground. However, I am not so sure that another imaginative, even if praxis-committed, text that is founded in Jesus' healing stories has a better chance of success. All this talk of bridging the gap between thought and practice seems to presuppose that individual Christian Dalits and grass root Christian communities are not living their theological aspirations. I am convinced that local communities have microscripts of liberative praxis that are operative, even of partially and tentatively. One may need to see liberation praxis as a collection of microactions, micro-rituals and micro-beliefs that work tacitly and cryptically. Liberative narratives may emerge when such sources are correlated with biblical speech-acts of Jesus including healing stories. Sourcing of Dalit theology must take place on the ground rather than for the ground. Our vocation as Dalit theologians thus may lie in construing theoretical validity for what is pragmatically already extant even of not fully effectual. After all, magnificent bridges of stone and steel that are constructed without the earthy canals of mud and straw may be conceptually stable but concretely irrelevant.

Sathianathan Clarke

Wesley Theological Seminary, Washington D. C.

\section{A Christian Pilgrim in India: The Spiritual Journey of Swami Abhishiktananda (Henri Le Saux). Harry oldmeadow. Bloomington, IN: World Wisdom, 2008, xvi + 316 pp.}


God's Harp String: The Life and Legacy of the Benedictine Monk Swami Abhishiktananda. William Skudlarek, editor. New York, NY: Lantern Books, 2010, x + 140 pp.

Jesus Christ: Quest and Context of Abhishikānanda (Henri Le Saux OSB). Santhosh Sebastian Cheruvally. New Delhi: ISPCK, 2011, xV + 246 pp.

Witness to the Fullness of Light: The Vision and Relevance of the Benedictine Monk Swami Abhishiktananda. William Skudlarek and Bettina Bäumer, editors. New York, NY: Lantern, 2011, 177.

A few years ago, a suggestion went out on the listserv of the Society of Hindu-Christian Studies that proposed a panel on Swami Abhishiktananda at the annual meeting of the Society, given his birth centenary in 2010. The general response was lackadaisical and a major scholar commented that the area was exhausted. However, in the space of four years four books have been published on Abhishiktananda. Two of them came out in conjunction with the one hundredth anniversary of Abhishiktananda's birth: God's Harp String and Witness to the Fullness of Light, both edited by William Skudlarek, with the second edited also by Bettina Bäumer. The former book is a collection of previously published essays and the latter a collection of essays presented at a recent conference. The other two books are by Harry oldmeadow and Santhosh Cheruvally. Oldmeadow explores parallels between Abhishiktananda's thought and the "perennial philosophy" of Frithjof Schuon. Cheruvally's is an analysis, from a Roman Catholic perspective, of Abhishiktananda's theological views of Christ. All four books are worthwhile and should be a part of the library of all Abhishiktananda scholars.
Abhishiktananda (1910-1973), originally known as Henri Le Saux, was a monk and a priest at St. Anne's Abbey in Kergonan, France. In 1948 he settled in India and in 1950 he and Fr. Jules Monchanin established the Benedictine monastery of Shantivanam, near Trichinopoly, with plans that it would conform to Hindu customs of renunciation as much as was permitted by Christian faith. Benedictine monasticism, historically, has taken on different forms in different countries, so Abhishiktananda and Monchanin concluded that it should take on a distinctively Indian form. In order to learn more about Indian monastic traditions, Abhishiktananda visited many institutions in south India, and thereby came to meet Ramana Maharshi in 1949. He made many subsequent visits to Ramana's ashram and he became deeply enamored with Advaita. Abhishiktananda spent the next two decades of his life, until his death, seeking immersion in Advaitic mysticism and relating it to Christianity.

Skudlarek's first book, God's Harp String, is a valuable work in that it draws together eleven previously published essays from the bulletins of the American Commission of Interreligious Dialogue and the now defunct Abhishiktananda Society. This review will discuss two of these 
essays. Bettina Bäumer's "Pilgrim and Hermit" gives a good summary of the main conclusions Abhishiktananda reached in the final years of his life. During his two decades in India he experienced great strain standing between Advaita and Christianity as he did, for the first beckons one beyond names and forms whilst the second is firmly rooted in the world of manifest reality. Abhishiktananda tried to reconcile theologically the two traditions, but found them too disparate to do so. Hence, in his final years he took solace in a mystical experience which he believed to be common to both Advaita and Christianity, but which transcends the doctrinal expressions of both. As Bäumer explains, "Abhishiktananda did not deny anything of what he previously believed; but everything was elevated to a level where the 'names and forms' became insignificant" (Skudlarek 2010, 56).

Those who write on Abhishiktananda often tend to be very accepting of his conclusions, especially as articulated by Bäumer. James Wiseman's essay is an exception. While giving an overall positive assessment, Wiseman identifies a bifurcation in Abhishiktananda's thought between language and experience, by which he dismisses concepts and doctrines in favor of mystical experience. Why assume, he wonders, that the doctrines of the great theologians of the past did not arise out of deep spiritual experiences? "How, after all, could anyone be so certain that the speculations of theologians like Saint Athanasius, Saint Basil, Saint Augustine, or Saint Thomas Aquinas on the Incarnation or the Trinity did not arise out of their own deep experience of these mysteries?" Skudlarek 2010, 99).

Skudlarek's second book, Witness, edited also by Bettina Bäumer, is a collection of papers presented at a 2010 symposium at Shantivanam, in honor of Abhishiktananda's one hundredth birth anniversary. Of the eight essays, this review will discuss those by George Gispert-Sauch, Bettina Bäumer, and Fausto Gianfreda. Gispert-Sauch's essay covers the influence of Abhishiktananda on the late Jacques Dupuis, one of the best known Catholic theologians in the area of the theology of religions. The essay gives some important details from the final years of
Abhishiktananda's life, not included in James Stuart's otherwise comprehensive biography, Swami Abhishiktānanda: His Life Told through His Letters (Delhi: ISPCK, 1989). These details concern the relationship between Abhishiktananda, Dupuis, Stuart, Vidyajyoti College of Theology, and Brotherhood House in New Delhi. In so doing, it gives the context for some of the essays Abhishiktananda wrote in the final years of his life, found in Intériorité et Révélation, (Sisteron: Presence, 1982).

Scholars writing on Abhishiktananda generally appreciate the influence of the Upanishads and Ramana Maharishi on him running consistently through his life, but there were also other Hindu influences on him. Bäumer, who is a scholar of Kashmiri Shaivism, gives extracts from Abhishiktananda's writing which shows the influence of Kashmiri Shaivism. For instance, Abhishiktananda criticized the dualism between nirguna and saguna Brahman found in some versions of Advaita. He rejected that in favor of the idea that the entirety of Brahman is present in all aspects of reality, even "the smallest mite, the grain of sand, the electron" (Abhishiktananda, quoted in Skudlarek and Bäumer 2011, 43).

Gianfreda's essay concerns Abhishiktananda and the Eucharist. It is well known that in his first decade in India, Abhishiktananda experienced much tension in celebrating the Eucharist. The issue is that the Eucharist is a rite which takes place in the world of names and forms, whereas Advaita involves the renunciation of rituals and calls one beyond names and forms. In spite of this tension, Abhishiktananda persisted with both his immersion in Advaita and his duties as a Catholic priest. Eventually the tension subsided and the Eucharist became a great joy to him (Skudlarek and Bäumer 2011, 103). This change came around 1964 in conjunction with Abhishiktananda's development of an indigenous version of the liturgy, involving Hindu texts and forms of worship (105ff). He reinterpreted it from an Advaitic perspective. For instance, he wrote that the Advaitic Christian has the potential to deeply appreciate the Eucharist, for he or she is the one who is aware of the presence of God behind 
everything, including every word and gesture of the liturgy (110).

Oldmeadow gives a comprehensive account of Abhishiktananda life and thought. Most such studies take a chronological approach, but oldmeadow takes a thematic one. This makes the book helpful and valuable. Oldmeadow gives a very fair portrayal of Abhishiktananda's life and thought, but he has a particular agenda. His prior work has not been on, primarily, either Asian religions or Abhishiktananda, but "Traditionalism." This is more commonly known as the "perennial philosophy," advocated in the past century by Ananda Coomaraswamy, Rene Guénon, and Frithjof Schuon. Oldmeadow spends the majority of the book laying out various aspects of Abhishiktananda's life and thought and then goes on to argue that his thought fits within the mold of "Traditionalism."

Traditionalism teaches that there is a consistent common strain of spirituality running through all traditions. Because there are many contradictions between religions, this may seem like a difficult thesis to argue. However, by positing a distinction between exoteric and esoteric dimensions of religion, one can bypass these contradictions (Oldmeadow 2008, 251-58). On the exoteric level, which is the level of the outward observables of belief and practice, there are clear differences between religions. On the deeper, inward level, reached by aspirants, there are no contradictions. On this level divine reality is directly experienced, without the intermediary of beliefs and practices (19). However, one should not disparage the exoteric level, for it is only through dedication to it that one can arrive at the esoteric. Oldmeadow considers this approach to questions of religious pluralism as highly satisfactory, for it gives one a way to be loyal to one's tradition while also not considering its beliefs and practices as ultimate, which would entail devaluing other religions (259).

Oldmeadow argues that Abhishiktananda's thought, especially in his final years, conforms to Traditionalism. There are two features of Abhishiktananda's thought, in particular, that he focuses on. First, Abhishiktananda argued that all religious forms are relative, that they are simply stepping stones to the ultimate mystery and are not themselves ultimate. Second, the ultimate mystery is esoteric or hidden in that most religious believers are not attuned to it, being wrapped up instead in outward beliefs and practices, not in an interior mystery. Although Abhishiktananda's thought conforms in these two ways to Traditionalism, oldmeadow points out that he was not a Traditionalist like Schuon. Schuon was clarifying the groundwork of the Traditionalist position and exploring its intellectual ramifications. Abhishiktananda, in contrast, did not identify himself with a Traditionalist school but was instead developed some Traditionalist insights in his struggle to resolve the tension between Christianity and Advaita (262-68).

Cheruvally's book began as his doctoral dissertation at the Gregorian University in Rome. The book surveys Abhishiktananda's writings to identify his theological understanding of Christ. Cheruvally identifies two main understandings, which he identifies as the "Trinitarian-Saccidānanda Christology" or "TSC" and the "Self-Awakening Christology" or "SAC" (Cheruvally 2011, 128). The TSC, which Abhishiktananda gradually developed in his first decade in India, combines Christian and Advaitic doctrines. Abhishiktananda identified the Son of the Holy Trinity with the Atman of the Upanishads, believing him to dwell deep within all human beings. This means that the Christian and the Advaitin both have something to learn from the other. The Advaitin experiences the ultimate reality as one, as the mystery of sat-cit-änanda, but through Christianity he or she can awaken to an experience of the communion which Abhishiktananda believes to lie at the heart of sat-cit-ānanda, the communion between the Father and the Son of the Holy Trinity. Likewise, through Advaita the Christian can realize Christ not simply as an external reality but as a presence deep in the soul, experiencing the mystery of sat-cit-ānanda (129-46).

In Abhishiktananda's final years, with some deep Advaitic mystical experiences taking place in his life, he developed the SAC (146-47). The Bible states that at Jesus' baptism the voice of God from heaven declared him to be his son. Abhishiktananda identified this experience of 
Jesus as identical to the Advaitic realization of unity with Brahman, and considered that experience to be the summit of all spirituality (147-50). He considered the potential for this realization to lie within all human beings, and hence within all religions: "The Christ I might present will be simply the I AM of my (every) deep heart, who can show himself in the dancing Shiva or the amorous Krishna!" (Abhishiktananda, quoted in Cheruvally 2011, 152). Whilst the earlier TSC conjoins some Christian and Advaitic concepts, the SAC involves dropping Christian dogmatic concepts in favor of Advaitic experience. "I feel too much, more and more, the blazing fire of this I $\mathrm{AM}$, in which all notions about Christ's personality, ontology, history, etc. have disappeared" (Abhishiktananda, quoted in Cheruvally 2011, 152).

Scholars who write on Abhishiktananda are generally accepting of these later conclusions as a natural outcome of a deep encounter between Advaita and Christianity. However, unlike many other scholars in this area, Cheruvally refuses to cast aside two thousand years of doctrinal tradition in the face of Abhishiktananda's encounter with Advaita. $\mathrm{He}$ argues that the content of Christian revelation cannot be altered simply because of a new context, which in this case is Advaita: "The unicity of Christ is primarily and essentially content specific in terms of God' saving and full revelation in Christ transmitted and preserved by the Church in Scripture and Tradition, and secondarily is context specific in terms of other cultural and religious experiences. ... it is the content that responds to the context and not the context which decides and alters the content" (167). Cheruvally general assessment of Abhishiktananda's life and thought was that it was a valuable experiment which shows valid directions for Christian theology to take in India, like the TSC, and directions that it should avoid, like the SAC.

Among these four recent books two opposing perspectives are identifiable. On the one hand, scholars like Bäumer and Oldmeadow are approving of Abhishiktananda's movement beyond the doctrinal specifics of religions to a mystical experience of unity. On the other hand, Wiseman and Cheruvally protest this abandonment of doctrine. Wiseman implies that doctrine is, in fact, based in some ways upon experience, whereas Cheruvally argues that the content of Christianity must respond to the context, which in this case is Advaita, rather than the context altering the content (Skudlarek 2010, 99; Cheruvally 2011, 167).

It might be worthwhile to play these contrasting perspectives off of each other. On what does Cheruvally base his claim that in Christianity the content should shape the context, not the reverse? Does he base this on tradition and authority? If so, Oldmeadow would respond that Cheruvally is bound up with the externals of religion, not looking to its inner depth. But one may ask, in turn, on what does Oldmeadow base his claim that there is a common esoteric level beyond the doctrinal level? This question is pertinent, given that the many contradictions between religions are evidence to the contrary. In fact, oldmeadow seems to suggest that the insights of Guénon and Schuon about religious pluralism rest upon an intuition rather than a reasoned argument: "Their grasp of metaphysical and cosmological principles seems to be more or less spontaneous, rather like the sudden solidification of certain crystalline structures" (Oldmeadow 2008, 266).

It would seem that Cheruvally would have us accept his perspective on the basis of tradition and oldmeadow his perspective on the basis of an intuition. Both of these bases seem to be equally matters of faith, rather than necessary conclusions. This issue merits more exploration. Is there something inherent to Christianity that makes it inappropriate to treat doctrines and rites as merely symbolic, or can they be regarded as merely provisional? Thinkers like Oldmeadow, Abhishiktananda, and John Hick give different arguments to support the view that the doctrines and rites of all religions should be treated as provisional. Is there a way in which Christianity, perhaps because of the implications of the doctrine of the Incarnation, cannot be appropriately fitted into this mold?

As mentioned at the outset of this review, an email on the SHCS listserv in recent years stated that the area of Abhishiktananda studies is about exhausted. The publication of four 
books in four years on Abhishiktananda's life and thought challenges this, and also points to possibilities for future research. For instance, Bäumer's essay (Skudlarek 2011, 31-46) leaves one wondering how the Kashmiri shaivite influence on Abhishiktananda developed and how it intermingled with other influences on him. Similarly, Gianfreda's essay leaves the reader wanting to know more about the specifics of Abhishiktananda's changing approaches to Christian liturgy (skudlarek 2011, 103-29). Likewise, Cheruvally's book leads one to want to know the specifics of how Abhishiktananda developed the TSC and how it was eclipsed by the SAC. Finally, the contrasting perspectives found among these four books show that Abhishiktananda's experiences and conclusions point to fundamental issues that go far beyond his life and example, and that these diverse perspectives need to be met head on and wrestled with. Still, although further research remains to be done, it is true that the area has been generally mapped out-the four books spend a lot of space covering material that has been covered in many earlier studies.

The lackadaisical response on the SHCS listserv may point to a different issue than whether or not the area of Abhishiktananda studies is exhausted. Abhishiktananda was a representative of an era in the encounter between Hinduism and Christianity when Advaita was considered by many scholars to be the summit and essence of Hinduism. Advaita was thus a main focus of efforts at comparison and dialogue. However, while Advaita continues to be a central interest the field of Hindu-Christian studies has expanded considerably. This is seen, for instance, in Francis Clooney's steady output on Śrī Vaișnavism and Michelle Voss Robert's recent comparative study of Kashmiri Śaivism. However, before dismissing the area of Abhishiktananda studies, one should ask not only the question of whether the area has been exhausted but the question of whether the lessons of his life have been integrated by the churches. While Abhishiktananda's life has generally been mapped out, the process of integrating the lessons of his life into the churches has only just begun.

Edward Ulrich

University of St. Thomas

\section{Bringing the Sacred Down to Earth: Adventures in Comparative Religion. Corinne G. Dempsey. New York: Oxford University}

\section{Press, 2012, 199 pages.}

IN Bringing the Sacred Down to Earth, Dempsey, former president of the society that publishes this journal, and author or editor of some of the most important recent works on Indian Christianity and American Hinduism, enters directly and explicitly into the project of comparative religion, as well as into scholarly debates about its utility and legitimacy. While the author acknowledges that comparative projects tend often towards essentialism and involve the scholarly imposition of foreign or anachronistic terms on contextualized, lived religious phenomena, she yet maintains hope that "by working contextually-and perhaps brazenly-across religious and cultural divides, the [chapters in the book] demonstrate instances in which concepts and performances of the sacred, when brought down to earth, can dismantle impositions and abstractions" (5).

The latter part of this quotation prefigures the author's emphasis, in each of the book's four comparative chapters, on the "dialogue" between "established hegemonic systems (asserted through colonialism, nationalism, scientism, and institutional religion) and localized religious expressions (found in folklore figures, democratizing theologies, and embodied and landed sacrality)," that, Dempsey argues, "talk back" (11). Put another way, Dempsey aims to diminish the danger that comparison will lead to unhelpful essentialisms and impositions by focusing "upon the ways 